\title{
HETEROCLADIUM HETEROPTERUM, A NEW MEMBER OF THE HUNGARIAN BRYOPHYTE FLORA
}

\author{
Kornél BARÁTH ${ }^{1}$ and Peter ErZBERGER ${ }^{2}$ \\ ${ }^{1}$ Department of Biology, Savaria Campus, Eötvös Loránd University, \\ H-9700 Szombathely, Károlyi Gáspár tér 4, Hungary; barath.kornel@sek.elte.hu \\ ${ }^{2}$ Belziger Str. 37, D-10823 Berlin, Germany; erzberger.peter@gmail.com
}

Baráth, K. \& Erzberger, P. (2019): Heterocladium heteropterum, a new member of the Hungarian bryophyte flora. - Studia bot. bung. 50(2): 323-329.

\begin{abstract}
During the systematic field studies aimed at exploring the recent bryophyte flora of the Köszeg Mts and in the framework of grid-cell based bryophyte recording, Heterocladium heteropterum was discovered in the valley of the stream Hármas-patak, as a new moss species for Hungary. The size of the population is estimated and the habitats are characterised. Taxonomic characterisation and illustrations are provided to distinguish it from $H$. dimorphum, which is the only related species growing in Hungary. Since $H$. heteropterum is known only in one location in the country so far, we suggest considering it as a critically endangered (CR) species.
\end{abstract}

Key words: bryophyte diversity, Hungary, Kőszeg Mts, moss species

\section{INTRODUCTION}

Heterocladium heteropterum (Brid.) Schimp. (Heterocladiaceae) is one of the first described species of the genus, published together with the descriptions of $H$. dimorphum and H. kurzii (SCHIMPER 1852). It is widespread in northern and western Europe, in the mountains of Central and southern Europe up to the alpine region, and with isolated occurrences in Turkey, Lebanon, Georgia, the Caucasus, and Azerbaijan (Wiggington \& BlockeEL 2014). H. heteropterum occurs in all countries surrounding Hungary (HODGETTS 2015). Since there is an old report of this species from the Austrian part of the Köszeg Mts (LATZel 1930, PURger et al. 1997) it was perhaps to be expected that $H$. heteropterum might occur in the Hungarian part of this mountain range as well. Although the species was already mentioned from Hungary, from the Pilis Mts by SzEPESFaLvy (1940, 1941, 1942), and this report was accepted by Boros (1953), it is clear now that only a collected specimen of Pterigynandrum filiforme was misidentified as $H$. heteropterum (BoROs 1968). Consequently $H$. heteropterum is missing in the latest Hungarian checklist (PAPP et al. 2010). 


\section{MATERIAL AND METHODS}

Extensive field studies have been conducted since 2015 to investigate the bryophyte diversity and distribution patterns in the Kőszeg Mts. Geographical coordinates of the $H$. heteropterum populations were determined using a Garmin eTrex-30 GPS. The photos were made with Canon SX50 camera and with stereomicroscope Olympus SZ51. The drawings of the details of $H$. heteropterum were made by the first author. The nomenclature of the bryophyte taxa follows PAPP et al. (2010) and HodgetTs (2015). In the case of the vascular plants the nomenclature follows KIRÁLY (2009).

\section{RESULTS AND DISCUSSION}

During the exploration of the bryophyte flora of the Köszeg Mts and in the framework of grid-cell based bryophyte recording (ERZBERGER 2012, ERZBerger \& Németh 2013), Heterocladium heteropterum was discovered on a steep slope of the valley of the stream Hármas-patak below Stájer-házak, ca 100 $\mathrm{m}$ from the border to Austria. Altogether seven colonies of $H$. heteropterum covering an overall area of $c a 1400 \mathrm{~cm}^{2}$ were found in earth-filled crevices of siliceous rock in mixed forest on 24 July, 2016 (B-Erzberger s. n., herbarium K. Baráth).

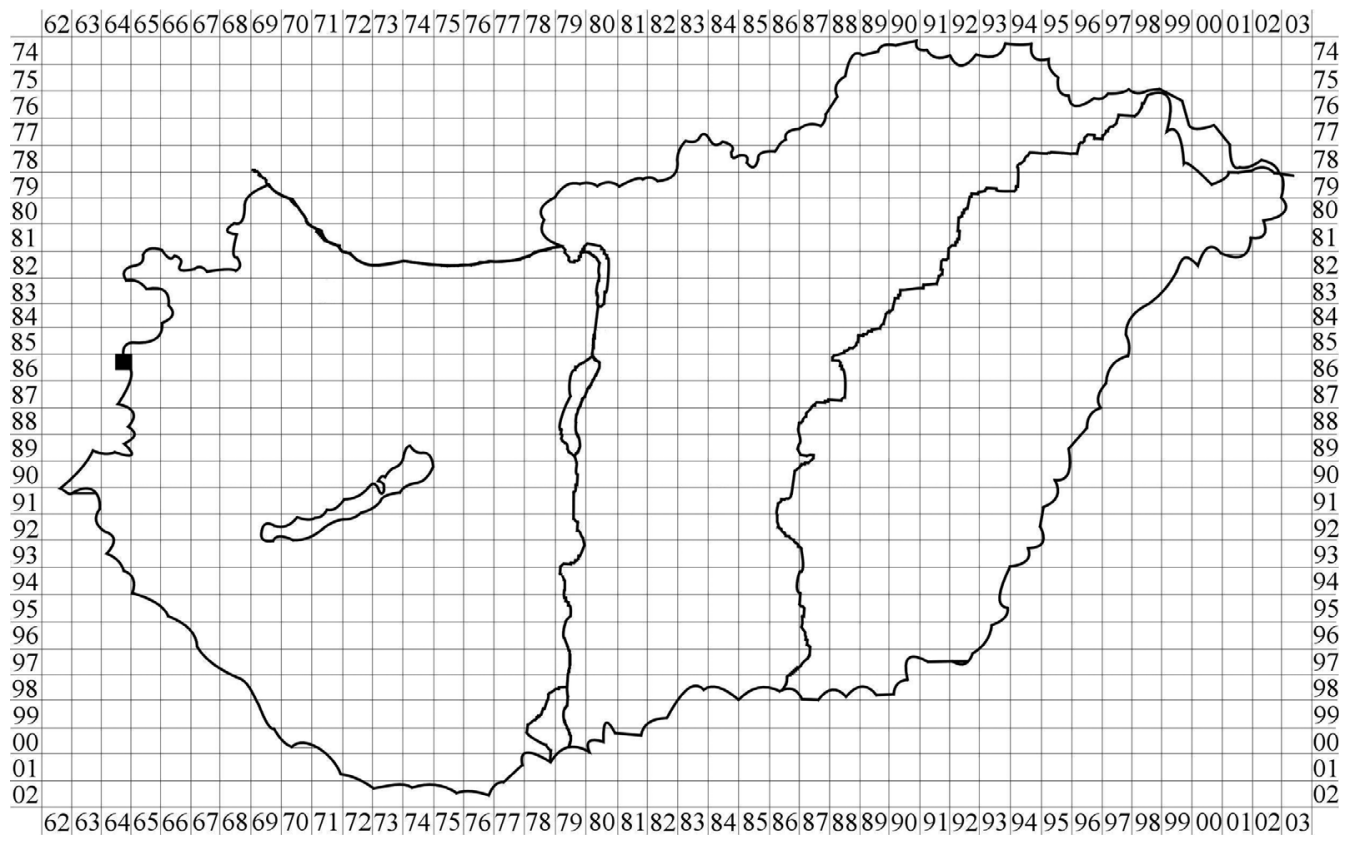

Fig. 1. Geographical locations of Heterocladium heteropterum in Hungary according to the grid of the Central European Mapping System. 
The centre of population was at $c a 400 \mathrm{~m}, 47.38703^{\circ} \mathrm{N}, 16.45706^{\circ} \mathrm{E}$, [8664.2] (Central European Mapping System; Ni KLFELD 1971) (Figs 1-2). The associated bryophytes were the following: Cynodontium polycarpon, Dicranella heteromalla, Dicranum scoparium, Hypnum cupressiforme, Isothecium myosuroides, Leucobryum juniperoideum, Poblia melanodon, Pseudotaxiphyllum elegans, Rhabdoweisia crispata and $R$. fugax. Vascular plants in the habitat include Asplenium ruta-muraria, A. trichomanes, Campanula rotundifolia, Corylus avellana, Cystopteris fragilis, Dryopteris carthusiana, Fagus sylvatica, Oxalis acetosella, Picea abies, Pinus sylvestris, Polypodium vulgare and Vaccinium myrtillus.

An additional population was found nearby: $c a 515 \mathrm{~m}$ to the SE of the first site, at $405 \mathrm{~m}, 47.38417^{\circ} \mathrm{N}, 16.46236^{\circ} \mathrm{E}, 14$ August 2016 (B-Erzberger 22286, herbarium K. Baráth). In this site the associated bryophytes were found to be Atrichum undulatum, Bartramia pomiformis, Hypnum cupressiforme, Lejeunea

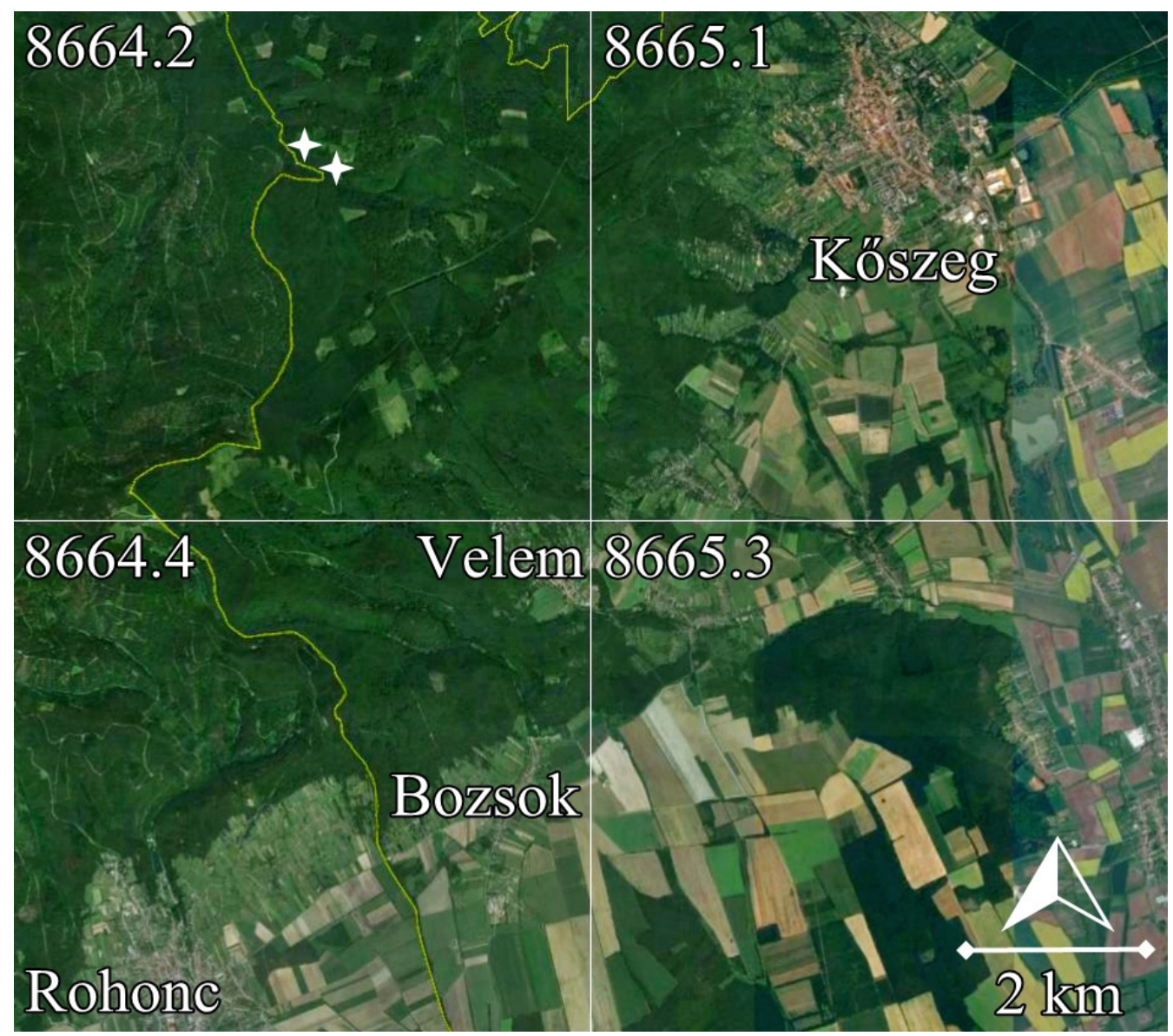

Fig. 2. Geographical location of the two new populations of Heterocladium heteropterum in the Köszeg Mts. 
cavifolia, Leucobryum juniperoideum, Polytrichum formosum, Pseudotaxiphyllum elegans, Rhabdoweisia crispata, R. fugax, Rhizomnium punctatum and Scapania nemorea. In the second site only two colonies of $H$. heteropterum covering an overall area of $c a 2700 \mathrm{~cm}^{2}$ were present.

\section{Short characterisation of Heterocladium heteropterum}

syn.: Hypnum heteropterum (Brid.) Hampe, Pterigynandrum heteropterum Brid., Pterigynandrum filiforme var. heteropterum (Brid.) Schimp., Thuidium heteropterum (Brid.) Kindb., Leptohymenium heteropterum (Brid.) Huebener, Pterogonium heteropterum (Brid.) Bruch, Pseudoleskea heteroptera (Brid.) Schimp., Pseudoleskeella heteroptera (Brid.) Kindb.

Plants slender, forming shoots up to about $3 \mathrm{~cm}$ long, dull green, rarely yellowish green, with roughly pinnate branching and down-curved stem leaves. Stem and branch leaves similar in shape but stem leaves about twice the size of the branch leaves. Stem leaves about 500-600 $\mu \mathrm{m}$ long, from an ovate base gradually narrowed to a short point, and erect spreading, apex acute to acuminate not reflexed. Costa double, less than halfway up the leaf. Capsules rare.

Heterocladium heteropterum usually grows on lime-free siliceous, moist, shaded rocks, often on vertical faces and near streams (Figs 3-6).

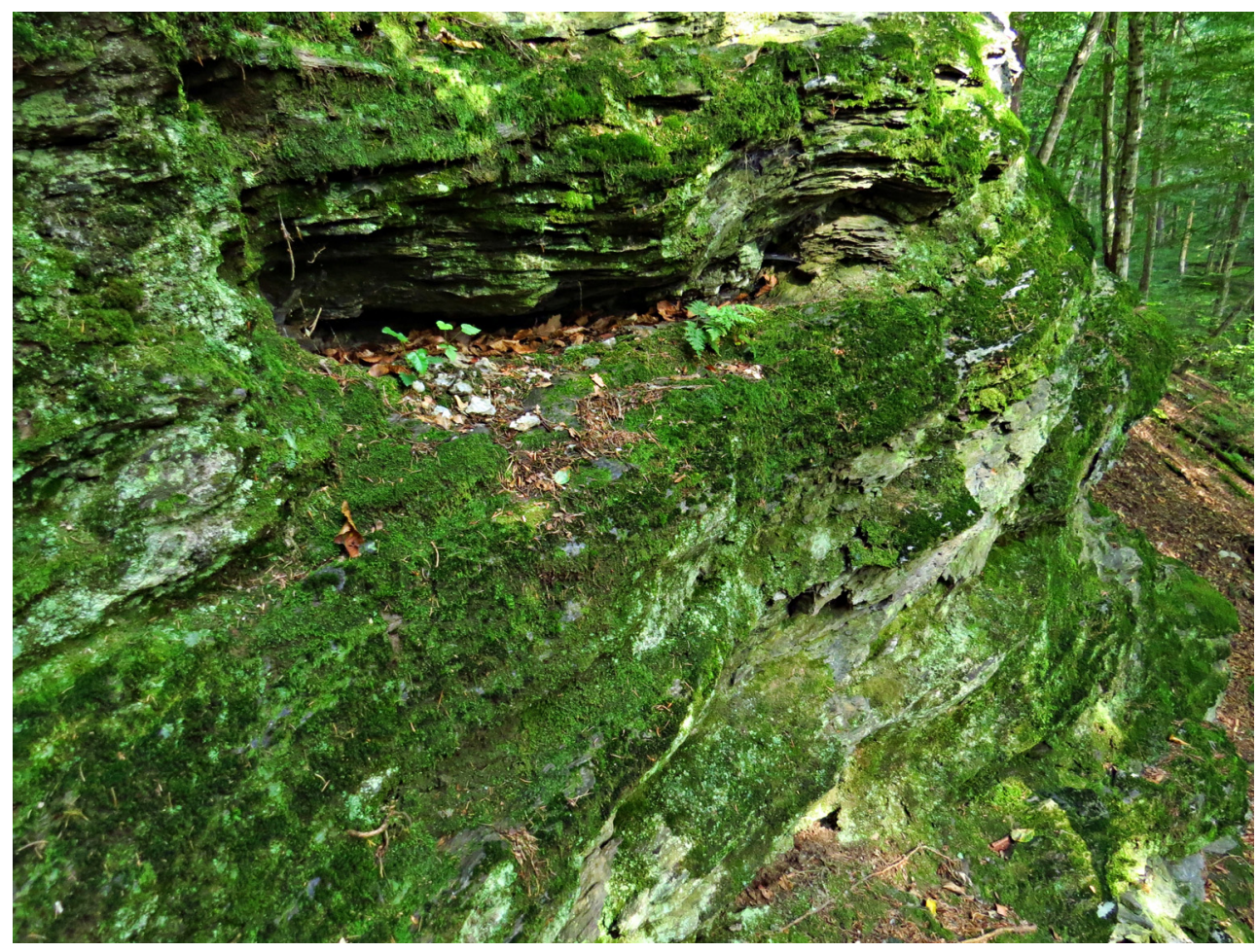

Fig. 3. Habitat of Heterocladium heteropterum in the Köszeg Mts. 


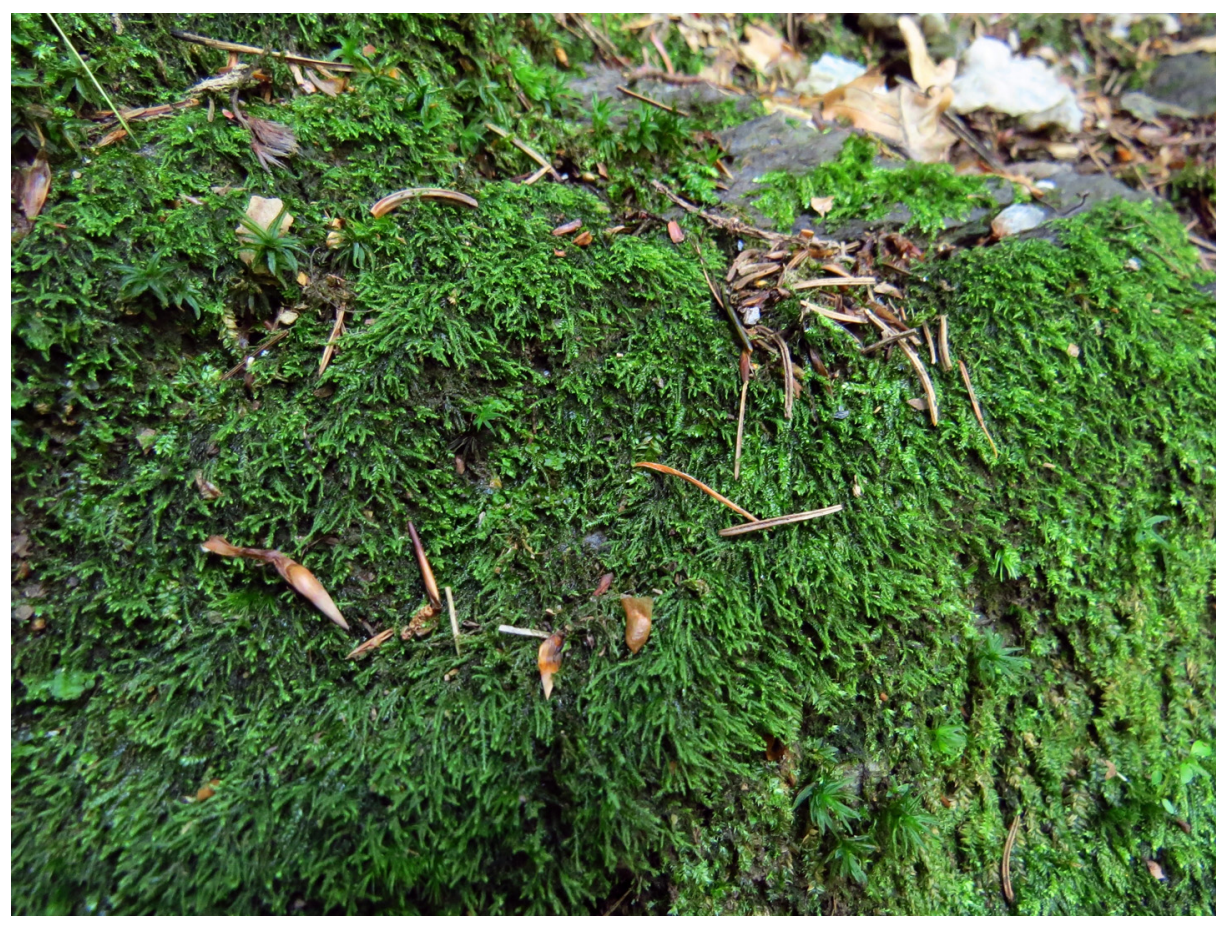

Fig. 4. Habit of Heterocladium heteropterum.

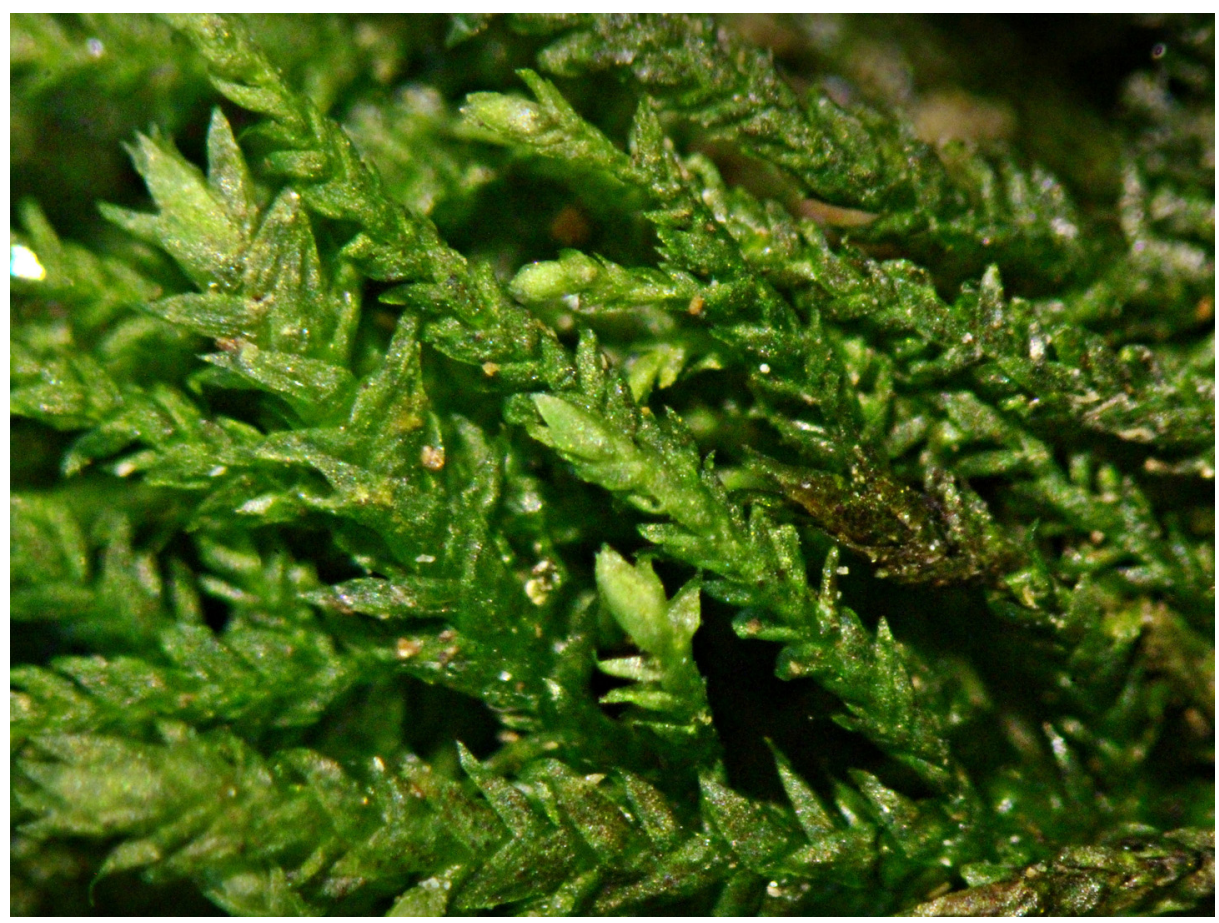

Fig. 5. Leafy shoots of Heterocladium heteropterum. 


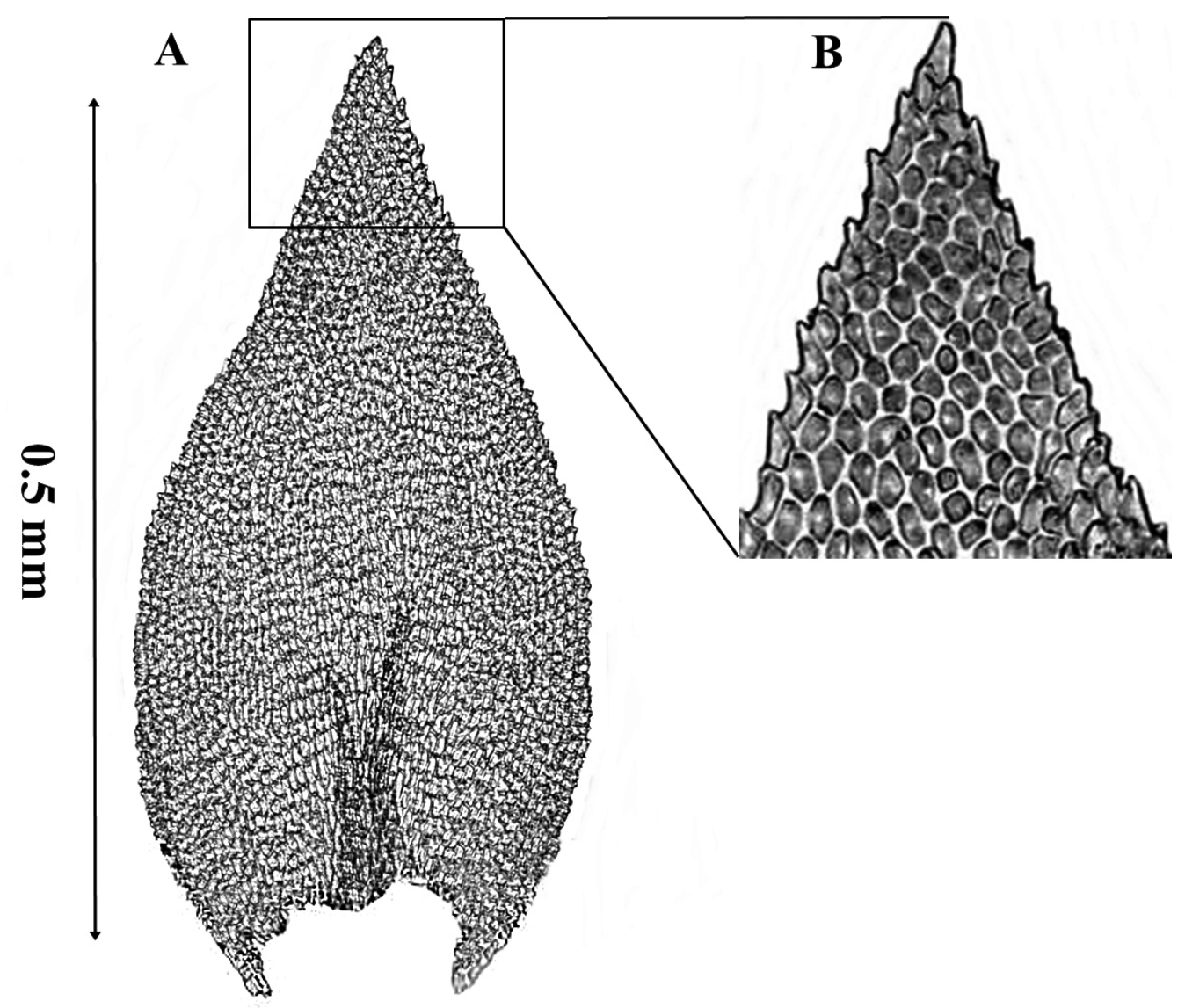

Fig. 6. Stem leaf (A) and apical cells (B) of Heterocladium heteropterum.

Heterocladium dimorphum the only related species growing in Hungary (PAPP et al. 2010) differs from $H$. heteropterum by strongly dimorphic leaves. Stem leaves reflexed, from a broad base abruptly narrowed to an acuminate point, branch leaves erecto-patent, shortly pointed. $H$. dimorphum usually grows in shady, woody habitats on loamy or gritty soil and at tree bases.

Acknowledgements - This study was supported by the "Development of international research environment for light pollution studies" EFOP-3.6.2-16-2017-00014.

Összefoglaló: A Kőszegi-hegység mohaflóráját feltáró terepmunkák során 2016-ban egy újabb, Magyarországra nézve új mohafaj került elő. A Heterocladium heteropterum a Kőszegi-hegység osztrák oldaláról már ismert volt, előfordulására Magyarországon is számítani lehetett. A faj Közép- és Dél-Európában elsősorban hegyvidéken, árnyékos szilikátos sziklákon, gyakran patakok 
közelében fordul elő. A Kőszegi-hegységben a Hármas-patak völgyéből 2 populáció összesen 9 telepe került elö, amelyek együttes kiterjedése $\mathrm{kb} .4100 \mathrm{~cm}^{2}$ volt. A Heterocladium nemzetségből a $H$. dimorphum fordul még elő Magyarországon, azonban az utóbbinak nemcsak méretükben, hanem alakjukban is eltérnek szár- és áglevelei. A két rokon faj elkülönítését az élőhelyi különbözőségek is elősegítik, ugyanis a $H$. dimorphum agyagos, vagy kavicsos talajon, útrézsűkben, fák tövében fordul elő. Mivel a $H$. heteropterum ez idáig csak a Kőszegi-hegységből került elő Magyarországon, ezért javasoljuk a vörös listán a súlyosan veszélyeztetett kategóriába $(\mathrm{CR})$ való besorolását.

\section{REFERENCES}

Boros Á. (1953): Magyarország mohái. (Bryophyta Hungariae). - Akadémiai Könyvkiadó, Budapest, $360 \mathrm{pp}$.

Boros Á. (1968): Bryogeographie und Bryoflora Ungarns. - Akadémiai Kiadó, Budapest, 466 pp.

ERzBerger P. (2012): Project plan: bryophyte mapping of Hungary. - Program and Abstracts, 8th Conference of European Committee for Conservation of Bryophytes, Budapest, 18-21 April 2012, p. 12.

ERZBerger P. \& Németh Cs. (2013): Mohatérképezés Magyarországon - eredmények az iniciális fázisból. [Bryophyte mapping in Hungary - results from the initial phase]. - Absztraktkötet, II. Aktuális eredmények a kriptogám növények kutatásában konferencia, Eger, p. 13.

HodgetTs N. G. (2015): Checklist and country status of European bryophytes - towards a new Red List for Europe. - Irish Wildlife Manuals 84: 1-112.

KIRÁLy G. (ed.) (2009): Újmagyarfüvészkönyv. - Magyarország hajtásosnövényei. - Határozókulcsok. [New Hungarian Herbal - The vascular plants of Hungary. - Identification key]. - Aggteleki Nemzeti Park Igazgatóság, Jósvafo, 616 pp.

Latzel A. (1930): Moose aus dem Komitate Vas u. einigen anderen Komitaten. - Magyar Bot. Lapok 29: 105-138.

Niklfeld, H. (1971): Bericht über die Kartierung der Flora Mitteleuropas. - Taxon 20: 545-571. https://doi.org/10.2307/1218258

Papp B., Erzberger P., Ódor P., Hock Zs., Szövényi P., Szurdoki E. \& Tóth Z. (2010): Updated checklist and red list of Hungarian bryophytes. - Studia bot. hung. 41: 31-59.

Purger Z., Balogh L., Papp B., Rajczy M. \& Szmorad F. (1997): A Kőszegi-hegység mohaflórája. [Bryoflora of the Köszeg Mountains]. - Tilia 5: 94-271.

SCHimper W. P. (1852): Heterocladium. - In: SChimper W. P. (ed.): Bryologia Europaea seu genera muscorum Europaeorum. E. Schweizerbart, Stuttgart, pp. 151-155.

Szepesfalvy J. (1940): Die Moosflora der Umgebung von Budapest und des Pilisgebirges I. - Ann. Mus. Nat. Hung. 33: 1-104.

Szepesfalvy J. (1941): Die Moosflora der Umgebung von Budapest und des Pilisgebirges II. Ann. Mus. Nat. Hung. 34: 1-71.

Szepesfalvy J. (1942): Die Moosflora der Umgebung von Budapest und des Pilisgebirges III. Ann. Mus. Nat. Hung. 35: 1-72.

Wiggington M. J. \& Blockeel T. L. (2014): Heterocladium heteropterum var. heteropterum. In: Blockeel T. L., Bosanquet S. D. S., Hill M. O. \& Preston C. D. (eds): Atlas of British and Irish Bryophytes. Vol. 2. Pisces, Newbury, 552 pp.

(submitted: 01.10.2019, accepted: 31.10.2019) 